\title{
Teaching Video NeuroImages: Pulsatile proptosis and wall-eyed bilateral internuclear ophthalmoplegia
}

Neurology ${ }^{\circledR}$ 2018;91:900. doi:10.1212/WNL.0000000000006463

In the Teaching Video NeuroImage "Pulsatile proptosis and wall-eyed bilateral internuclear ophthalmoplegia" by Papageorgiou et al., there is an error in the arrow placement in figure 2. Please see the correct version below. The authors regret the error.

Figure 2 Coronal brain CT and axial brain MRI

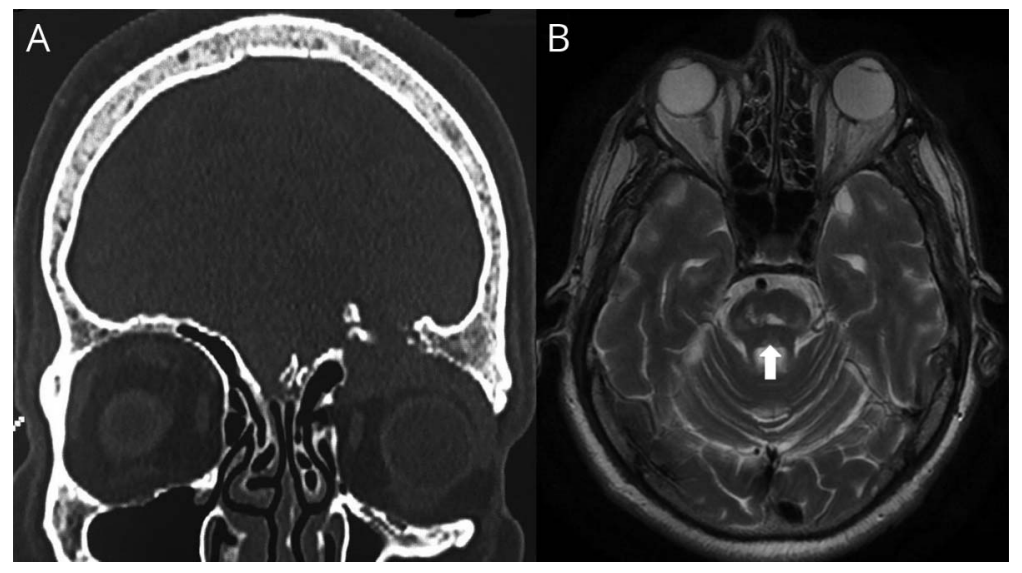

(A) Coronal brain CT shows fracture of the left orbital roof with an associated meningocele. (B) T2-weighted axial brain MRI demonstrates an acute infarction at the midline of the midbrain tegmentum, which involves the medial longitudinal fasciculus bilaterally.

\section{Reference}

1. Papageorgiou E, Tsironi EE, Androudi S, Koltsidopoulos P. Teaching Video NeuroImages: pulsatile proptosis and wall-eyed bilateral internuclear ophthalmoplegia. Neurology 2018;90:e1542-e1543. 


\title{
Neurology
}

\section{Teaching Video NeuroImages: Pulsatile proptosis and wall-eyed bilateral internuclear ophthalmoplegia \\ Neurology 2018;91;900 \\ DOI 10.1212/WNL.0000000000006463}

This information is current as of November 5, 2018

\author{
Updated Information \& \\ Services \\ including high resolution figures, can be found at: \\ http://n.neurology.org/content/91/19/900.full \\ References \\ This article cites 1 articles, 1 of which you can access for free at: \\ http://n.neurology.org/content/91/19/900.full\#ref-list-1 \\ Permissions \& Licensing \\ Information about reproducing this article in parts (figures,tables) or in \\ its entirety can be found online at: \\ http://www.neurology.org/about/about_the_journal\#permissions \\ Reprints \\ Information about ordering reprints can be found online: \\ http://n.neurology.org/subscribers/advertise
}

Neurology ${ }^{\circledR}$ is the official journal of the American Academy of Neurology. Published continuously since 1951, it is now a weekly with 48 issues per year. Copyright (O) 2018 American Academy of Neurology. All rights reserved. Print ISSN: 0028-3878. Online ISSN: 1526-632X.

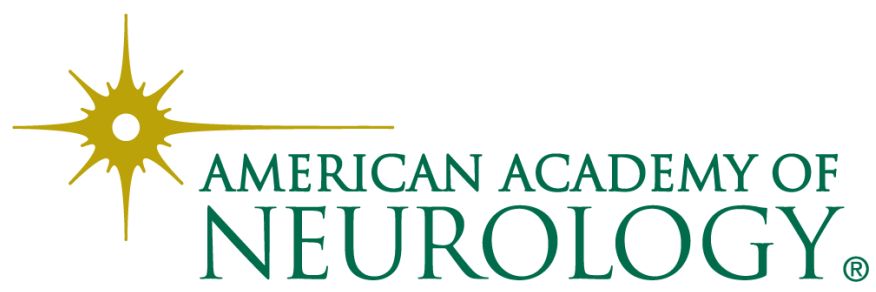

